\title{
Dimensional Stability Improvement of Corn Stalk Biocomposites Using Two-part Lignin-derived Binder Optimized with Response Surface Methodology
}

\begin{abstract}
Yuan Yuan, ${ }^{\mathrm{a}}$ Sidan Li, ${ }^{\mathrm{b}}$ Feng Jiao, ${ }^{\mathrm{c}}$ Guinan Shen, ${ }^{\mathrm{a}}$ Lei Yan, ${ }^{\mathrm{a}}$ and Weidong Wang ${ }^{\mathrm{a}, *}$
To strengthen the dimensional stability of enzymatically treated corn stalk (ECS) biocomposites, hybrid modified lignosulfonate (HML) was used as a binder to fabricate reinforced ECS/HML composites with evaluation by response surface methodology. The effects of the preparation treatment on the enzymatic conditions, as well as the modified lignosulfonate dosage on the physicomechanical properties of the ECS/HML composites, were all evaluated. The optimum preparation parameters were determined via the Box-Behnken experimental design. High mass concentrations of laccase-vanillin and an appropriate modified lignosulfonate dosage for a relatively short enzymatic pretreatment time led to reduced residual stresses and improved dimensional properties. The optimum conditions that minimized thickness swelling (TS) and water adsorption (WA) without significantly compromising the biocomposite mechanical properties were determined to be $25 \mathrm{~g} / \mathrm{L}$ laccase-vanillin, $118.8 \mathrm{~min}$ enzymatic pretreatment time, and 15 wt $\%$ modified lignosulfonate. The ECS/HML composites that were treated under the optimal conditions resulted in an approximate $42 \%$ reduction in the dimensional properties without any significant decline in mechanical properties when compared to ECS panels. Unlike the loose structure of ECS biocomposites, the ECS/HML composites had a laminar shape with firm morphology.
\end{abstract}

Keywords: Corn stalk; Enzymatic pretreatment; Hybrid modified lignosulfonate; Box-Behnken design; Physicomechanical properties

Contact information: a: Heilongjiang Provincial Key Laboratory of Environmental Microbiology and Recycling of Argo-Waste in Cold Region, College of Life Science and Technology, Heilongjiang Bayi Agricultural University, Daqing 163319, China; b: Institute of New Rural Development, Heilongjiang Bayi Agricultural University, Daqing 163319, China; c: College of Agronomy, Heilongjiang Bayi Agricultural University, Daqing 163319, China; *Corresponding author:wwdcyy@126.com

\section{INTRODUCTION}

To decrease the emission of toxic volatiles and to protect both the environment and human health, considerable efforts have been devoted to the development of particleboards using natural-derived binders (Widyorini et al. 2005a). Such particleboards are biocomposites that are formed without the presence of synthetic resin. It has been shown that their self-bonding strength could be improved by activating the chemical components of board constituents during steam or heat treatment (Widyorini et al. 2005b). The main methods employed for this purpose are based on heating or biological treatments (González-García et al. 2011; Wang et al. 2011, 2013; Wu et al. 2011), steam explosion (Xu et al. 2004), and combined processes. These approaches are often less hazardous than panel manufacturing with formaldehyde-based adhesives. In addition, bioproducts 
prepared without synthetic binders are biodegradable, recyclable, and can be disposed of in environmentally friendly ways (Nadhari et al. 2013).

Composite panels can be made of several crops (Thamae et al. 2008; Shah 2013), such as corn stalk, wheat straw (Wang and Sun 2002), kenaf core (Xu et al. 2003), cotton stalk (Zhou et al. 2010), rice husk (Ndazi et al. 2006), and castor stalk (Grigoriou and Ntalos 2001). Corn is the most produced cereal worldwide, surpassing wheat and rice (Jarabo et al. 2013). The production of corn and its wastes increases each year. Corn residues are industrial raw material sources that can potentially be used in several applications, including human consumption, energy (Yan et al. 2012), fuel (Gao et al. 2017), carbon materials, and chemical production (Ioannidou et al. 2009). The industrial usage of agricultural residues from the forest industry may effectively reduce the production cost, increase the sustainability of the panel manufacturing industry (Juárez et al. 2007), and minimize air pollution caused by the combustion of corn residues. However, farmers harvest only the grains, and most of the residues, including the stalks and husks, are burned or disposed of due to several limitations like collection cost and farming conditions (Çöpür et al. 2007). For biocomposites, Wu et al. (2011) manufactured binderless fiberboards from corn stalk that was pretreated with white-rot fungus. The pretreatment process significantly increased the mechanical properties and improved the crystallinity of the fiberboards without using any synthetic adhesives. However, most binderless biocomposites exhibit deficiencies that limit their industrial applications (Yuan et al. 2011). Therefore, the methods for reinforcing the interactions between components are key for improving the physicomechanical properties of biocomposites prepared without synthetic binders.

Lignin significantly affects the manufacturing of binderless biocomposites. Most studies have focused on technical lignin, such as kraft lignin (Velásquez et al. 2003; Mancera et al. 2011a, 2011b) and lignosulfonate (Jin et al. 2011; Ji and Guo 2018; Ji et al. 2018), both of which are generated from the papermaking industry. However, the low reactivity of lignin has limited its commercial use; thus it is often discarded or burned to generate energy or recover chemicals. Less than 5\% of the world's global lignin supply has been used as low-value compounds ( $\mathrm{Hu}$ et al. 2011). Lignin oxidation with $\mathrm{H}_{2} \mathrm{O}_{2}$ may effectively improve its safe utilization because water is used to break it down, replacing organic solvents and reducing environmental issues. Alkaline aqueous solutions have been determined to be the best reaction medium compared to acidic or neutral environments $(\mathrm{Hu}$ and Guo 2015).

Hybrid modified lignosulfonate (HML) is a type of lignin-based binder with modified ammonium lignosulfonate and polyethylenimine (Yuan and Guo 2014; Yuan et al. 2014). Hybrid modified lignosulfonate has a better environmental impact in wood fiber composites because it is a formaldehyde-free binder (Yuan and Guo 2016, 2017). However, only a handful of studies so far have reported on applications related to modified technical lignin in biocomposites using enzymatic treatments. In this study, the feasibility of using HML as a natural binder and enzymatic pretreated corn stalk (ECS) particles as raw materials to manufacture biocomposites was evaluated at a representative factory that had an approximate production capacity of $145,000 \mathrm{~m}^{3} /$ year in Harbin, an urban region in the northeast of China. The Box-Behnken design (BBD) was applied to investigate the effects of variable interactions on the physicomechanical properties of ECS/HML composites. Fourier transform infrared spectrometry (FTIR) and scanning electron microscopy (SEM) were also employed to compare the chemical structures of the binderless biocomposites before and after the introduction of HML. 


\section{EXPERIMENTAL}

\section{Materials}

Corn stalks obtained from Anda (Heilongjiang province, China) were air-dried and stored in jute bags. The corn stalks were chipped through a hacker chipper and then reduced into smaller particles using a knife ring flaker (FW-100 high-speed shredder; HuaYi Instrument Co., Ltd., Changzhou, China). The obtained particles were dried to a moisture content of 5\% and passed through 40-mesh to 60-mesh sieve for separation, then stored for the manufacturing of corn stalk biocomposites. The content of ash according to GB/T 742 (2008), ethanol-benzene extractives according to GB/T 10741 (2008), Klason lignin according to GB/T 747 (2003), holocellulose according to GB/T 2677.10 (1995), and $\alpha$ cellulose according to GB/T 744 (2004) were measured. The hemicelluloses content was calculated by subtracting the cellulose content from the holocellulose content. The average chemical compositions of the initial particles were determined to be $4.6 \%$ ash, $14.9 \%$ extractives, $16.7 \%$ lignin, $45.6 \%$ cellulose, and $22.5 \%$ hemicelluloses. Due to the overlap in the test parameters, the total chemical composition exceeded 100\% (104.4\%), which was expected (Angles et al. 1997). Ammonium lignosulfonate from Shenyang Xingzhenghe Chemical (Shenyang, China) was used as it was received, with the composition content determined to be $51.9 \%$ total lignin, $27.1 \%$ carbohydrates, $10.6 \%$ ash, and $4.6 \%$ moisture. Laccase was purchased from Wuhan Yuancheng Technology Development (Wuhan, China) and stored at $-10{ }^{\circ} \mathrm{C}$. The activity of the commercial laccase powder was approximately 4000 U/g. Vanillin (4-hydroxy-3-methoxybenzaldehyde) was purchased from Shanghai Adams Reagent Co., Ltd. (Shanghai, China). Polyethylenimine (PEI) was obtained from Shanghai UN Chemical (Shanghai, China). The molecular weight of PEI was 75,000 in 50 wt \% aqueous solution. All other chemicals used were of analytical grade.

\section{Enzymatic treatment of the corn stalks}

The corn stalk particles were first pretreated with laccase-vanillin according to previous reports (Yuan and Guo 2013). Briefly, the dried corn stalk particles were suspended in deionized water to yield a $5.0 \mathrm{wt} \%$ suspension at a $\mathrm{pH}$ of 5 , and they were then mixed using a JJ-1 precision-power motor stirrer (Changzhou Wanfeng Instrument Co., Ltd., Changzhou, China). Next, the suspension was stirred with an oxygen stream at temperatures from $45^{\circ} \mathrm{C}$ to $47^{\circ} \mathrm{C}$ for $180 \mathrm{~min}$. The mass ratio of laccase to vanillin was set to 2.56:100 for $1 \mathrm{~L}$ of the desired oxidation system. After the pretreatment, the particles were transferred to gauze for dewatering and were air-dried at $30^{\circ} \mathrm{C}$. They were then dried for $1 \mathrm{~h}$ at $100{ }^{\circ} \mathrm{C}$ to eliminate enzyme reaction. The target moisture content of the pretreated corn stalk particles was set between $4 \%$ and $6 \%$.

\section{Preparation of the $H M L$}

Two-part lignin-derived binder was prepared through an oxidation reaction and combination technology using ammonium lignosulfonate (AL) and PEI according to previous reports (Yuan et al. 2014). Briefly, $50 \mathrm{~g}$ of AL powder was alkalinized in $100 \mathrm{~g}$ water adjusted to a $\mathrm{pH}$ of 10 . Next, $30 \% \mathrm{H}_{2} \mathrm{O}_{2}$ dosage based on dry weight to lignosulfonate was added to the solution. After heating for $30 \mathrm{~min}$ at $60{ }^{\circ} \mathrm{C}$, the mixture was concentrated to form a $20 \mathrm{wt} \%$ modified ammonium lignosulfonate (MAL) solution. Hybrid modified lignosulfonate was prepared by mixing MAL with PEI at a weight ratio of 7:1 for $30 \mathrm{~min}$. 


\section{Manufacturing of the ECS/HML composites}

The ECS particles were mixed with HML at different proportions in a SHR-10A high-speed blender (Zhangjiagang Yunfan Machinery Co., Ltd., Zhangjiagang, China). The mixed particles were fixed into the mat of a $250 \mathrm{~mm} \times 250 \mathrm{~mm}$ forming box. The target density of all biocomposites was determined to be $0.8 \mathrm{~g} / \mathrm{cm}^{3} \pm 0.03 \mathrm{~g} / \mathrm{cm}^{3}$ with a target thickness of $5 \mathrm{~mm}$. For reproducibility, each group of experiments under these sets of conditions was replicated three times. The corn stalk biocomposites issued from ECS were prepared and used as controls.

\section{Methods}

Physicomechanical properties of ECS/HML composites

For each test, the ECS/HML composites were cut into three test samples according to $\mathrm{GB} / \mathrm{T} 17657$ (2013) after conditioning at $20{ }^{\circ} \mathrm{C} \pm 2{ }^{\circ} \mathrm{C}$ and $65 \% \pm 5 \%$ relative humidity (RH). The test samples were set to $200 \mathrm{~mm} \times 50 \mathrm{~mm}$ for the modulus of rupture (MOR) and the modulus of elasticity (MOE) tests, and $50 \mathrm{~mm} \times 50 \mathrm{~mm}$ for the internal bonding strength (IB) test. A loading speed of $5 \mathrm{~mm} / \mathrm{min}$ was selected for the MOR and the MOE tests and $2 \mathrm{~mm} / \mathrm{min}$ for the IB test. The thickness swelling (TS) and water absorption (WA) were also set to $50 \mathrm{~mm} \times 50 \mathrm{~mm}$ using three replicates. The specimens were first immersed in water at $20^{\circ} \mathrm{C} \pm 1{ }^{\circ} \mathrm{C}$ and then their thickness and weight changes were measured after $24 \mathrm{~h}$. The load-bearing particleboard properties of GB/T 4897 (2015) were followed as $\mathrm{MOR} \geq 15 \mathrm{MPa}, \mathrm{MOE} \geq 2.2 \mathrm{GPa}, \mathrm{IB} \geq 0.45 \mathrm{MPa}$, and $24 \mathrm{~h} \mathrm{TS} \leq 22 \%$.

\section{FTIR and SEM characterization}

The FTIR spectroscopy of prepared corn stalks, lignosulfonates, and ECS/HML specimens were characterized using a Nicolet Magna-IR 560 (ThermoFisher Scientific, Madison, USA). The spectra were recorded at wavelengths ranging from $4000 \mathrm{~cm}^{-1}$ to 500 $\mathrm{cm}^{-1}$. Each sample was scanned 40 times at resolution of $4 \mathrm{~cm}^{-1}$. Following the IB tests, the SEM results were collected to evaluate the morphological changes of the ECS panels and the ECS/HML composites on a Sirion 200 (FEI Company, Hillsboro, USA) microscope.

\section{Experimental design}

A Box-Behnken experimental design with three independent parameters and three various levels was adopted using Design-Expert 8.0.6 software (Stat-Ease Inc., Minneapolis, USA). A total of 17 experiments at a central point were employed to determine the variables that influence the ECS/HML composites' performance. This method allows the establishment of statistical relationships between the experimental variables and response variables to describe the nature of the response surface and elucidate the optimal manufacturing conditions. These features should, in turn, allow for predicting the optimal board properties. Table 1 lists the design matrix and mechanical properties data of the obtained ECS/HML composites.

The three critical parameters that affected the physicomechanical properties of the ECS/HML composites were the mass concentration of laccase-vanillin $\left(X_{\mathrm{A}}\right)$, the enzymatic pretreated time $\left(X_{\mathrm{B}}\right)$, and the modified lignosulfonate dosage $\left(X_{\mathrm{C}}\right)$. These parameters were selected as the independent variables based on preliminary experiments. The dependent variables (response), which include MOR, MOE, IB, $24 \mathrm{~h} \mathrm{TS}$, and $24 \mathrm{~h} \mathrm{WA}$, were then evaluated. An analysis of variance (ANOVA) was performed for each response at a confidence level of $95 \%$. All data were expressed using the average of three replicates 
along with their coefficient of variation $(\mathrm{CV})$. The $\mathrm{CV}$ observations for the samples from the ECS/HML composites compared well with those of the control.

Table 1. Experimental Design of Coded Factors and Results of BBD for Physicomechanical Properties of ECS/HML Composites

\begin{tabular}{|c|c|c|c|c|c|c|c|c|c|}
\hline \multirow{2}{*}{ Coded } & \multirow{2}{*}{\multicolumn{5}{|c|}{ Factors }} & \multicolumn{4}{|c|}{ Range and Levels } \\
\hline & & & & & & Low $(-1)$ & \multirow{2}{*}{\multicolumn{2}{|c|}{$\frac{\text { Medium (0) }}{20}$}} & High (1) \\
\hline A & \multicolumn{5}{|c|}{$\begin{array}{l}\text { Mass concentration of laccase- } \\
\text { vanillin }(\mathrm{g} / \mathrm{L})\end{array}$} & 15 & & & 25 \\
\hline$B$ & \multirow{2}{*}{\multicolumn{5}{|c|}{$\begin{array}{l}\text { Enzymatic pretreated time (min) } \\
\text { Modified lignosulfonate dosage } \\
(w t \%)\end{array}$}} & 120 & \multicolumn{2}{|c|}{150} & 180 \\
\hline C & & & & & & 10 & \multicolumn{2}{|c|}{15} & 20 \\
\hline \multirow{2}{*}{ Run } & \multicolumn{3}{|c|}{ Factors } & \multirow{2}{*}{$\begin{array}{l}\text { Density } \\
\left(\mathrm{g} / \mathrm{cm}^{3}\right)\end{array}$} & \multirow{2}{*}{$\begin{array}{l}\text { MOR } \\
(\mathrm{MPa})\end{array}$} & \multirow{2}{*}{$\begin{array}{l}\text { MOE } \\
(\mathrm{GPa})\end{array}$} & \multirow{2}{*}{$\begin{array}{c}\mathrm{IB} \\
(\mathrm{MPa})\end{array}$} & \multirow{2}{*}{$\begin{array}{c}\text { TS } \\
24 \mathrm{~h}(\%)\end{array}$} & \multirow{2}{*}{$\begin{array}{c}\text { WA } \\
24 \mathrm{~h}(\%)\end{array}$} \\
\hline & $A$ & $B$ & $\mathrm{C}$ & & & & & & \\
\hline 1 & 0 & 1 & -1 & 0.79 & $\begin{array}{l}18.47 \\
(4.6)^{*}\end{array}$ & $\begin{array}{l}1.75 \\
(5.6) \\
\end{array}$ & $\begin{array}{l}0.50 \\
(5.2)\end{array}$ & $\begin{array}{c}24.56 \\
(7.4)\end{array}$ & $\begin{array}{c}30.40 \\
(9.2)\end{array}$ \\
\hline 2 & 0 & -1 & 1 & 0.82 & $\begin{array}{c}26.74 \\
(6.2)\end{array}$ & $\begin{array}{l}2.47 \\
(4.6)\end{array}$ & $\begin{array}{l}1.16 \\
(5.2)\end{array}$ & $\begin{array}{l}17.24 \\
(9.2)\end{array}$ & $\begin{array}{l}21.23 \\
(8.3)\end{array}$ \\
\hline 3 & 0 & 0 & 0 & 0.80 & $\begin{array}{c}18.90 \\
(5.2)\end{array}$ & $\begin{array}{l}1.81 \\
(4.8)\end{array}$ & $\begin{array}{l}0.67 \\
(5.2)\end{array}$ & $\begin{array}{c}22 \\
(7.9)\end{array}$ & $\begin{array}{c}28.40 \\
(7.8)\end{array}$ \\
\hline 4 & 1 & -1 & 0 & 0.83 & $\begin{array}{c}28.45 \\
(6.3) \\
\end{array}$ & $\begin{array}{l}3.07 \\
(5.7)\end{array}$ & $\begin{array}{l}1.24 \\
(5.2)\end{array}$ & $\begin{array}{l}19.21 \\
(6.4)\end{array}$ & $\begin{array}{c}22.55 \\
(9.2)\end{array}$ \\
\hline 5 & 0 & 0 & 0 & 0.81 & $\begin{array}{c}18.20 \\
(5.8)\end{array}$ & $\begin{array}{l}1.89 \\
(4.2)\end{array}$ & $\begin{array}{l}0.57 \\
(5.2)\end{array}$ & $\begin{array}{c}21.75 \\
(6.3)\end{array}$ & $\begin{array}{c}30.10 \\
(7.1)\end{array}$ \\
\hline 6 & 0 & 0 & 0 & 0.79 & $\begin{array}{c}19.70 \\
(5.5)\end{array}$ & $\begin{array}{l}1.80 \\
(6.2)\end{array}$ & $\begin{array}{l}0.64 \\
(5.2)\end{array}$ & $\begin{array}{l}18.9 \\
(7.1)\end{array}$ & $\begin{array}{l}26.90 \\
(8.5)\end{array}$ \\
\hline 7 & 1 & 0 & -1 & 0.80 & $\begin{array}{c}24.75 \\
(4.9)\end{array}$ & $\begin{array}{l}2.94 \\
(3.2)\end{array}$ & $\begin{array}{l}0.90 \\
(5.2)\end{array}$ & $\begin{array}{c}20.14 \\
(3.5)\end{array}$ & $\begin{array}{c}29.10 \\
(7.8)\end{array}$ \\
\hline 8 & 0 & 0 & 0 & 0.81 & $\begin{array}{l}18.9 \\
(5.4)\end{array}$ & $\begin{array}{l}2.04 \\
(5.3)\end{array}$ & $\begin{array}{l}0.67 \\
(5.2)\end{array}$ & $\begin{array}{c}22.16 \\
(7.4)\end{array}$ & $\begin{array}{c}28.40 \\
(6.8)\end{array}$ \\
\hline 9 & -1 & 0 & -1 & 0.79 & $\begin{array}{c}10.46 \\
(4.7) \\
\end{array}$ & $\begin{array}{r}1.09 \\
(3.8) \\
\end{array}$ & $\begin{array}{l}0.25 \\
(5.2)\end{array}$ & $\begin{array}{r}35.47 \\
(4.4)\end{array}$ & $\begin{array}{c}45.63 \\
(8.2)\end{array}$ \\
\hline 10 & 0 & 1 & 1 & 0.82 & $\begin{array}{c}16.72 \\
(6.7)\end{array}$ & $\begin{array}{l}1.76 \\
(3.7) \\
\end{array}$ & $\begin{array}{l}0.46 \\
(5.2)\end{array}$ & $\begin{array}{c}29.64 \\
(6.2)\end{array}$ & $\begin{array}{c}30.47 \\
(9.1)\end{array}$ \\
\hline 11 & 1 & 0 & 1 & 0.82 & $\begin{array}{c}25.74 \\
(5.1)\end{array}$ & $\begin{array}{l}2.95 \\
(3.4) \\
\end{array}$ & $\begin{array}{l}1.08 \\
(5.2)\end{array}$ & $\begin{array}{c}20.23 \\
(7.2)\end{array}$ & $\begin{array}{c}20.46 \\
(7.5)\end{array}$ \\
\hline 12 & 1 & 1 & 0 & 0.80 & $\begin{array}{c}26.40 \\
(6.4)\end{array}$ & $\begin{array}{l}2.48 \\
(4.9)\end{array}$ & $\begin{array}{l}0.89 \\
(5.2)\end{array}$ & $\begin{array}{c}18.97 \\
(6.9)\end{array}$ & $\begin{array}{c}25.64 \\
(7.6)\end{array}$ \\
\hline 13 & -1 & 1 & 0 & 0.79 & $\begin{array}{c}22.40 \\
(4.9)\end{array}$ & $\begin{array}{l}2.39 \\
(4.6)\end{array}$ & $\begin{array}{l}0.57 \\
(5.2)\end{array}$ & $\begin{array}{c}24.84 \\
(7.4)\end{array}$ & $\begin{array}{l}30.4 \\
(8.2)\end{array}$ \\
\hline 14 & -1 & -1 & 0 & 0.81 & $\begin{array}{c}18.74 \\
(5.4)\end{array}$ & $\begin{array}{l}1.77 \\
(4.6)\end{array}$ & $\begin{array}{l}0.55 \\
(5.2)\end{array}$ & $\begin{array}{r}26.47 \\
(7.4)\end{array}$ & $\begin{array}{c}39.74 \\
(6.2)\end{array}$ \\
\hline 15 & 0 & -1 & -1 & 0.79 & $\begin{array}{l}9.75 \\
(4.8)\end{array}$ & $\begin{array}{l}0.98 \\
(5.6)\end{array}$ & $\begin{array}{l}0.30 \\
(5.2)\end{array}$ & $\begin{array}{l}38.4 \\
(8.5)\end{array}$ & $\begin{array}{c}45.40 \\
(8.2)\end{array}$ \\
\hline 16 & -1 & 0 & 1 & 0.82 & $\begin{array}{c}23.40 \\
(5.3)\end{array}$ & $\begin{array}{l}2.78 \\
(4.3)\end{array}$ & $\begin{array}{l}0.74 \\
(5.2)\end{array}$ & $\begin{array}{c}21.97 \\
(7.4)\end{array}$ & $\begin{array}{c}27.70 \\
(9.3)\end{array}$ \\
\hline 17 & 0 & 0 & 0 & 0.80 & $\begin{array}{c}19.40 \\
(5.1)\end{array}$ & $\begin{array}{l}2.01 \\
(4.6)\end{array}$ & $\begin{array}{l}0.61 \\
(5.2)\end{array}$ & $\begin{array}{c}20.32 \\
(9.1)\end{array}$ & $\begin{array}{c}25.70 \\
(8.2)\end{array}$ \\
\hline \multicolumn{4}{|c|}{ Control } & 0.80 & $\begin{array}{l}8.93 \\
(6.4) \\
\end{array}$ & $\begin{array}{l}1.39 \\
(6.7) \\
\end{array}$ & $\begin{array}{l}0.42 \\
(5.2)\end{array}$ & $\begin{array}{c}43.25 \\
(8.1)\end{array}$ & $\begin{array}{c}84.23 \\
(9.1)\end{array}$ \\
\hline \multicolumn{4}{|c|}{$\begin{array}{l}\text { GB/T } 4897(2015) \\
\text { load-bearing } \\
\text { particleboard }\end{array}$} & & $\geq 15$ & $\geq 2200$ & 0.45 & $\leq 22$ & - \\
\hline
\end{tabular}

${ }^{*}$ Coefficient of variation 


\section{RESULTS AND DISCUSSION}

\section{Data Analysis and Regression Models}

The analysis of variance p-values for the mechanical properties of the ECS/HML composites are presented in Table 2 . All p-values below 0.05 revealed significant model terms, while values above 0.05 indicated insignificant model terms (Alslaibi et al. 2013). Meanwhile, p-values below 0.0001 would imply that all models of mechanical properties were significant and there is only a $0.01 \%$ chance that such values could occur due to noise.

Table 2. Analysis of Variables for $p$-Value of Parameters and Their Interactions

\begin{tabular}{|c|c|c|c|c|c|c|c|c|c|c|}
\hline $\begin{array}{l}\text { Resp } \\
\text { onse }\end{array}$ & Model & $X_{A}$ & $X_{B}$ & $X_{C}$ & $X_{A} X_{B}$ & $X_{A} X_{C}$ & $X_{B} X_{C}$ & $\mathrm{X}_{\mathrm{A}^{2}}$ & $X_{B}{ }^{2}$ & $X_{c^{2}}$ \\
\hline MOR & $\begin{array}{c}< \\
0.001\end{array}$ & $\begin{array}{c}< \\
0.001\end{array}$ & $\begin{array}{l}0.88 \\
36 \text { ns } \\
\end{array}$ & $\begin{array}{c}< \\
0.001\end{array}$ & $\begin{array}{c}0.00 \\
55 \\
\end{array}$ & $\begin{array}{c}< \\
0.001\end{array}$ & $\begin{array}{c}< \\
0.001\end{array}$ & $\begin{array}{c}< \\
0.001\end{array}$ & $\begin{array}{c}0.03 \\
69 \\
\end{array}$ & $\begin{array}{c}0.00 \\
07 \\
\end{array}$ \\
\hline MOE & $\begin{array}{c}< \\
0.001\end{array}$ & $\begin{array}{c}< \\
0.001\end{array}$ & $\begin{array}{l}0.83 \\
13^{\mathrm{ns}} \\
\end{array}$ & $\begin{array}{c}< \\
0.001\end{array}$ & $\begin{array}{c}0.00 \\
16 \\
\end{array}$ & 0.0002 & 0.0005 & $\begin{array}{c}< \\
0.001\end{array}$ & $\begin{array}{l}0.16 \\
31 \text { ns } \\
\end{array}$ & $\begin{array}{l}0.22 \\
83^{\mathrm{ns}} \\
\end{array}$ \\
\hline IB & $\begin{array}{c}< \\
0.001\end{array}$ & $\begin{array}{c}< \\
0.001\end{array}$ & $\begin{array}{c}0.00 \\
03\end{array}$ & $\begin{array}{c}< \\
0.001\end{array}$ & $\begin{array}{c}0.00 \\
42\end{array}$ & 0.0100 & $\begin{array}{c}< \\
0.001\end{array}$ & 0.0002 & $\begin{array}{l}0.35 \\
28 \mathrm{~ns}\end{array}$ & $\begin{array}{l}0.05 \\
96 \mathrm{~ns}\end{array}$ \\
\hline TS & $\begin{array}{c}< \\
0.001\end{array}$ & $\begin{array}{c}< \\
0.001\end{array}$ & $\begin{array}{l}0.37 \\
40^{\mathrm{ns}} \\
\end{array}$ & $\begin{array}{c}< \\
0.001\end{array}$ & $\begin{array}{l}0.59 \\
04^{\text {ns }} \\
\end{array}$ & 0.0009 & $\begin{array}{c}< \\
0.001\end{array}$ & $\begin{array}{c}0.2092 \\
\text { ns }\end{array}$ & $\begin{array}{c}0.00 \\
85\end{array}$ & $\begin{array}{c}0.00 \\
02\end{array}$ \\
\hline WA & $\begin{array}{c}< \\
0.001\end{array}$ & $\begin{array}{c}< \\
0.001\end{array}$ & $\begin{array}{c}0.01 \\
52\end{array}$ & $\begin{array}{c}< \\
0.001\end{array}$ & $\begin{array}{c}0.00 \\
23\end{array}$ & 0.0101 & $\begin{array}{c}< \\
0.001\end{array}$ & $\begin{array}{c}0.6949 \\
\text { ns }\end{array}$ & $\begin{array}{l}0.06 \\
50 \mathrm{~ns}\end{array}$ & $\begin{array}{c}0.00 \\
56\end{array}$ \\
\hline
\end{tabular}

ns Not signficant

From the ANOVA results (Table 1), the enzymatic pretreated time levels showed no significant effect on the physicomechanical properties, except for IB and WA. The factors positively affected the physicomechanical properties under different conditions, except for IB that was lower at low-level preparation conditions.

Table 3. Regression Models of Mechanical Properties and Dimensional Stability of ECS/HML Composites

\begin{tabular}{|c|c|c|c|c|c|}
\hline Regression Models & $\mathrm{R}^{2}$ & $\begin{array}{c}\text { Predicted } \\
\mathrm{R}^{2}\end{array}$ & $\begin{array}{c}\text { Adjusted } \\
\mathrm{R}^{2}\end{array}$ & $\begin{array}{c}\text { Adequate } \\
\text { Precision }\end{array}$ & $\begin{array}{c}\text { Std. } \\
\text { dev. }\end{array}$ \\
\hline $\begin{array}{c}\mathrm{MOR}=19.02+3.79 X_{A}+3.65 X_{C}- \\
1.43 X_{A} X_{B}-2.99 X_{A} X_{C}-4.69 X_{B} X_{C}+ \\
4.07 X_{A}^{2}+0.91 X_{B}^{2}-2.01 X_{C}^{2}\end{array}$ & 0.9918 & 0.9112 & 0.9812 & 35.458 & 0.72 \\
\hline $\begin{array}{c}\mathrm{MOE}=1910.62+426.52 X_{A}+ \\
400.24 X_{C}-305.30 X_{A} X_{B}-421.58 X_{A} X_{C} \\
-371.38 X_{B} X_{C}+607.91 X^{2}\end{array}$ & 0.9827 & 0.8457 & 0.9605 & 23.333 & 122.38 \\
\hline $\begin{array}{c}\mathrm{IB}=0.63+0.25 X_{A}-0.10 X_{B}+0.19 X_{C} \\
-0.093 X_{A} X_{B}-0.078 X_{A} X_{C}-0.22 X_{B} X_{C}+ \\
0.16 X_{A}^{2}\end{array}$ & 0.9890 & 0.9084 & 0.9749 & 30.296 & 0.044 \\
\hline $\begin{array}{c}\mathrm{TS}=21.03-3.77 X_{A}-3.69 X_{C}+ \\
3.40 X_{A} X_{C}+6.56 X_{B} X_{C}+2.18 X_{B}^{2}+ \\
4.26 X_{C}^{2}\end{array}$ & 0.9808 & 0.8958 & 0.9562 & 21.680 & 1.23 \\
\hline $\begin{array}{c}\mathrm{WA}=27.90-5.71 X_{A}-1.50 X_{B}- \\
6.33 X_{C}+3.11 X_{A} X_{B}+2.32 X_{A} X_{C}+ \\
6.06 X_{B} X_{C}+2.56 X_{C}^{2}\end{array}$ & 0.9856 & 0.9572 & 0.9770 & 24.296 & 1.33 \\
\hline
\end{tabular}



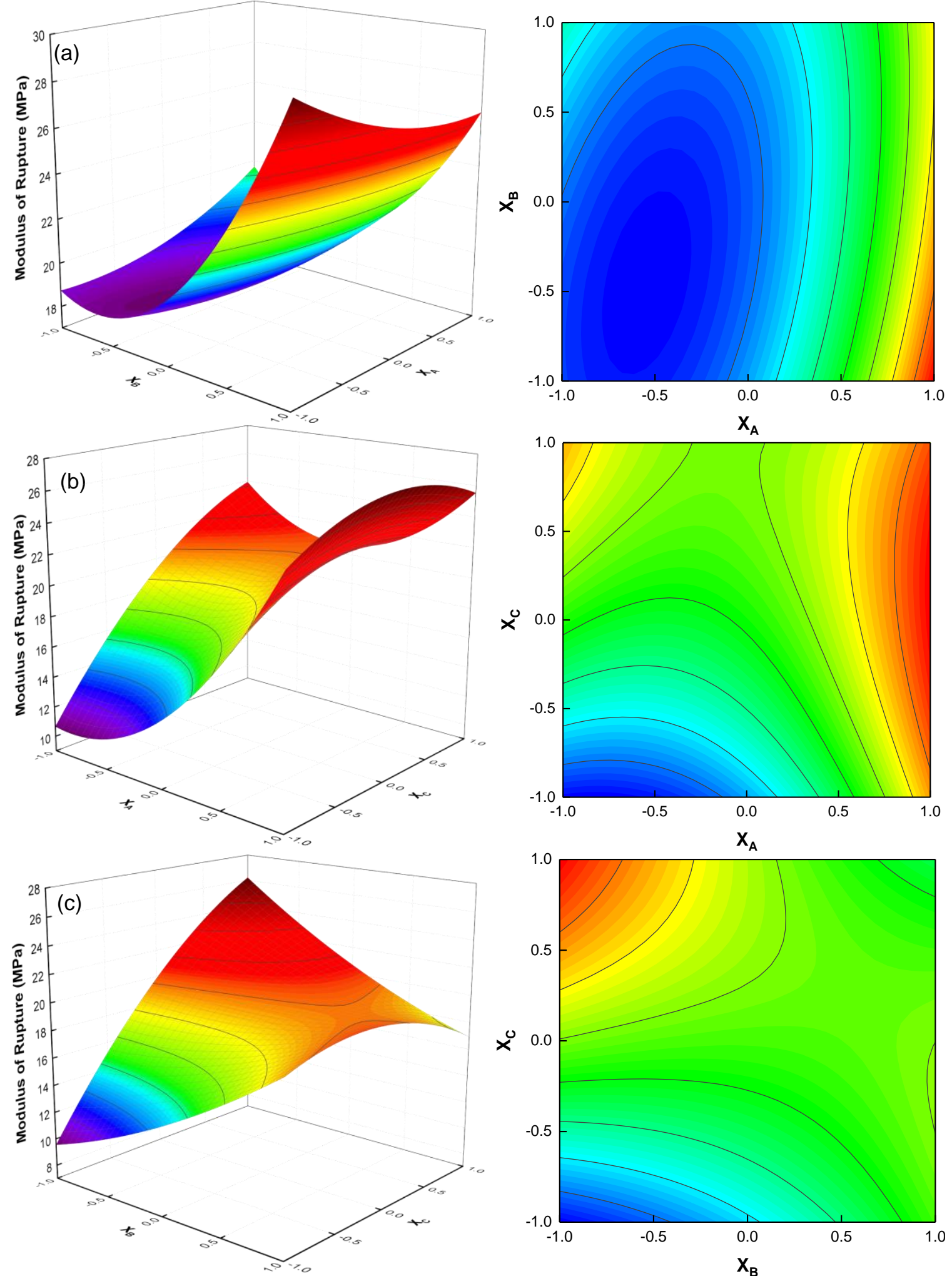

Fig. 1. Response surface plots for MOR as a function of: (a) $X_{\mathrm{A}} v s$. $X_{\mathrm{B}}$, (b) $X_{\mathrm{A}} v s$. $X_{\mathrm{C}}$, and (c) $X_{\mathrm{B}}$ vs. $X_{\mathrm{C}}$ 
A series of estimates yielded five quadratic models associating the mechanical properties to the preparation conditions. These included $X_{\mathrm{A}}, X_{\mathrm{B}}$, and $X_{\mathrm{C}}$ (Table 3). The models fit well, and all $\mathrm{R}^{2}$ values were higher than 0.98 . All predicted $\mathrm{R}^{2}$ values agreed with the adjusted $\mathrm{R}^{2}$ values. Values of adequate precision greater than 4 are desirable (Muthukumar et al. 2003). The effects of MOR, MOE, and IB on the mechanical properties and dimensional stability (TS and WA) were investigated more deeply in later sections.

\section{Mechanical Properties}

To further analyze the effects of parameters $X_{\mathrm{A}}, X_{\mathrm{B}}$, and $X_{\mathrm{C}}$ on the mechanical properties of ECS/HML composites, the response surfaces were plotted as threedimensional (3D) plots. From the generated data obtained from the same test, the MOR and MOE were analyzed together. The fitted models for MOR and MOE yielded $\mathrm{R}^{2}$ values of 0.9918 and 0.9827 , respectively. Table 2 shows that the variables $X_{\mathrm{A}}$ and $X_{\mathrm{C}}$ significantly affected the MOR and MOE while variable $X_{\mathrm{B}}$ was insignificant.

Figures 1a to $1 \mathrm{c}$ show the effects of $3 \mathrm{D}$ response surfaces of $X_{\mathrm{A}}, X_{\mathrm{B}}$, and $X_{\mathrm{C}}$ on MOR according to the quadratic mathematical model. At a constant enzymatic pretreatment time (Fig. 1a), the MOR values significantly increased as the mass concentration of laccase-vanillin increased. At a constant mass concentration of laccasevanillin (1) (Fig. 1b), changes in the trends of MOR were divided into two stages. First, the modified lignosulfonate dosage $\left(X_{\mathrm{C}}\right)$ ranged from -1 to 0 . As the $X_{\mathrm{C}}$ increased, the MOR value increased, indicating that the crosslinking of the modified lignosulfonate with PEI improved the mechanical strength. Therefore, lignin cross-linked with PEI could be used as a corn panel adhesive. Second, the $X_{\mathrm{C}}$ ranged from 0 to 1 .

The MOR values decreased as the modified lignosulfonate dosage increased, suggesting that high amounts of HML could deteriorate the mechanical performance of the ECS/HML composites. The negative value of $X_{\mathrm{B}}$ meant that the decreased enzymatic pretreatment time increased the MOR values (Fig. 1c). Therefore, excess lignin-based binder can be cured before the final formation of ECS/HML composites. The high amounts of cured lignin-based binder made the samples fragile, which led to the mechanical damage. The same influencing trend was investigated for the MOE and the same explanations of MOR were valid for MOE (Figs. 2a to 2c). The maximum MOR and MOE values of the ECS/HML composites determined at a constant enzymatic pretreatment time of $120 \mathrm{~min}$ were $29.18 \mathrm{MPa}$ and $3.148 \mathrm{GPa}$, respectively.

The response surface plots for the IB are shown in Figs. 3a to 3c. The IB represented the strength of the bonding between the particles and should be considered to ensure that the panels do not delaminate during post-processing. The fitted model for IB yielded an $\mathrm{R}^{2}$ value of 0.9890 . Thus, all single factors and interactions between the mass concentration of laccase-vanillin and other variables $\left(X_{\mathrm{A}} X_{\mathrm{B}}, X_{\mathrm{A}} X_{\mathrm{C}}\right)$ were significant for the IB (Table 2). The effects of all variables on IB depicted similar trends. The internal bonding strength generally increased with $X_{\mathrm{A}}$ with $X_{\mathrm{B}}$ and with the enzymatic pretreatment time $\left(X_{\mathrm{A}}\right)$. However, Fig. 3 shows that IB was significantly affected by $X_{\mathrm{A}}$ and $X_{\mathrm{C}}$ but moderately affected by time $\left(X_{\mathrm{B}}\right)$ in the ECS/HML composites. This suggested that the lignin of corn stalk particles melted well at selected enzymatic pretreated concentrations and selected times, forming strong interparticle bonds at lignin and cellulosic surface areas (Back 1987). Hence, the mechanical properties of ECS/HML composites decreased in the presence of excess amounts of HML. Thus, increased modified lignosulfonate dosage and enzymatic concentration of laccase-vanillin improved the mechanical properties of ECS/HML composites below $15 \mathrm{wt} \%$ HML. 

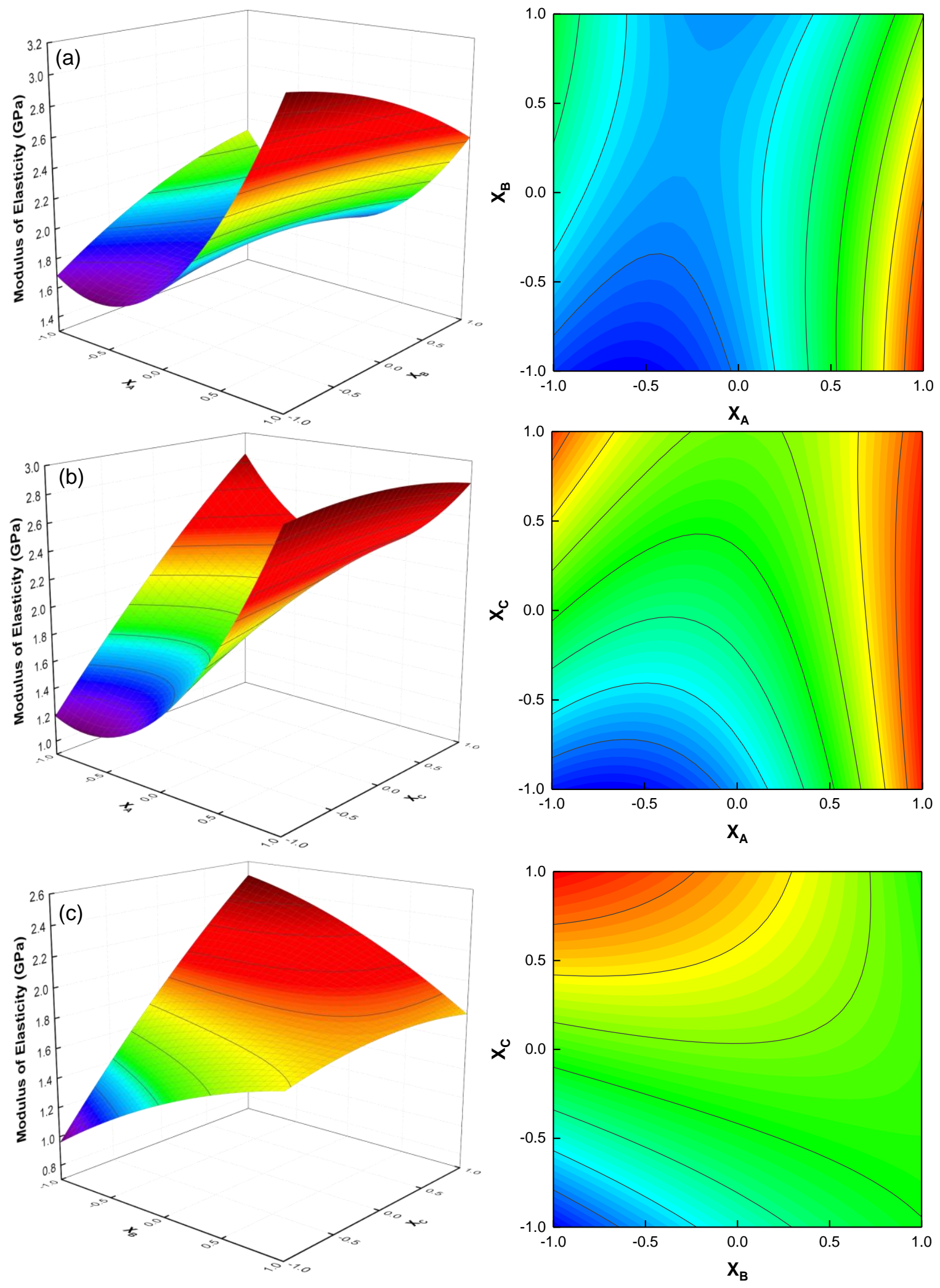

Fig. 2. Response surface plots for the MOE as a function of: (a) $X_{\mathrm{A}} v s . X_{\mathrm{B}}$, (b) $X_{\mathrm{A}} v s$. $X_{\mathrm{C}}$, and (c) $X_{\mathrm{B}}$ vs. $X_{\mathrm{C}}$ 

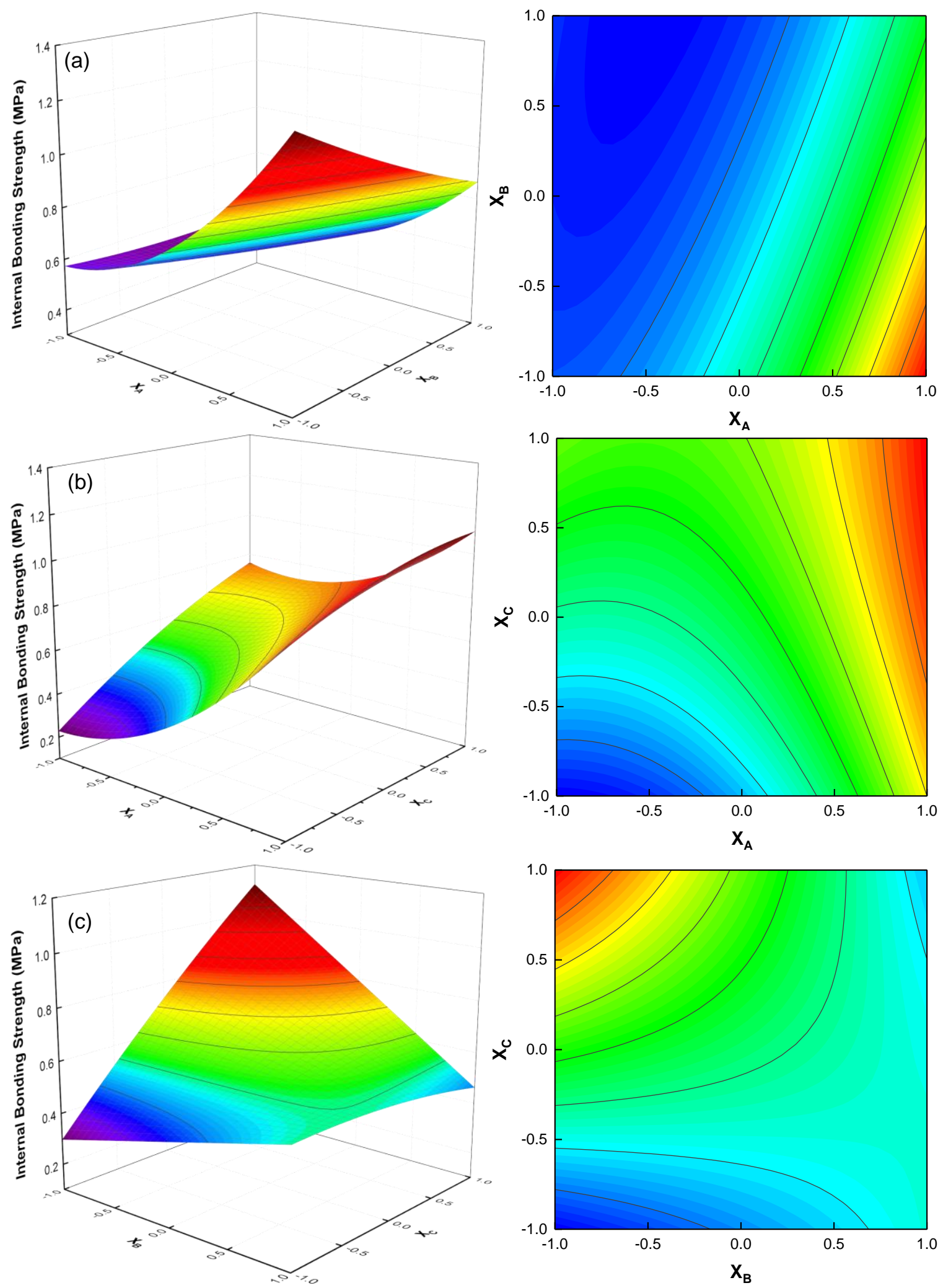

Fig. 3. Response surface plots for IB as a function of: (a) $X_{\mathrm{A}} v s . X_{\mathrm{B}},(\mathrm{b}) X_{\mathrm{A}} v s$. $X_{\mathrm{C}}$, and (c) $X_{\mathrm{B}} v s$. $X_{\mathrm{C}}$ 

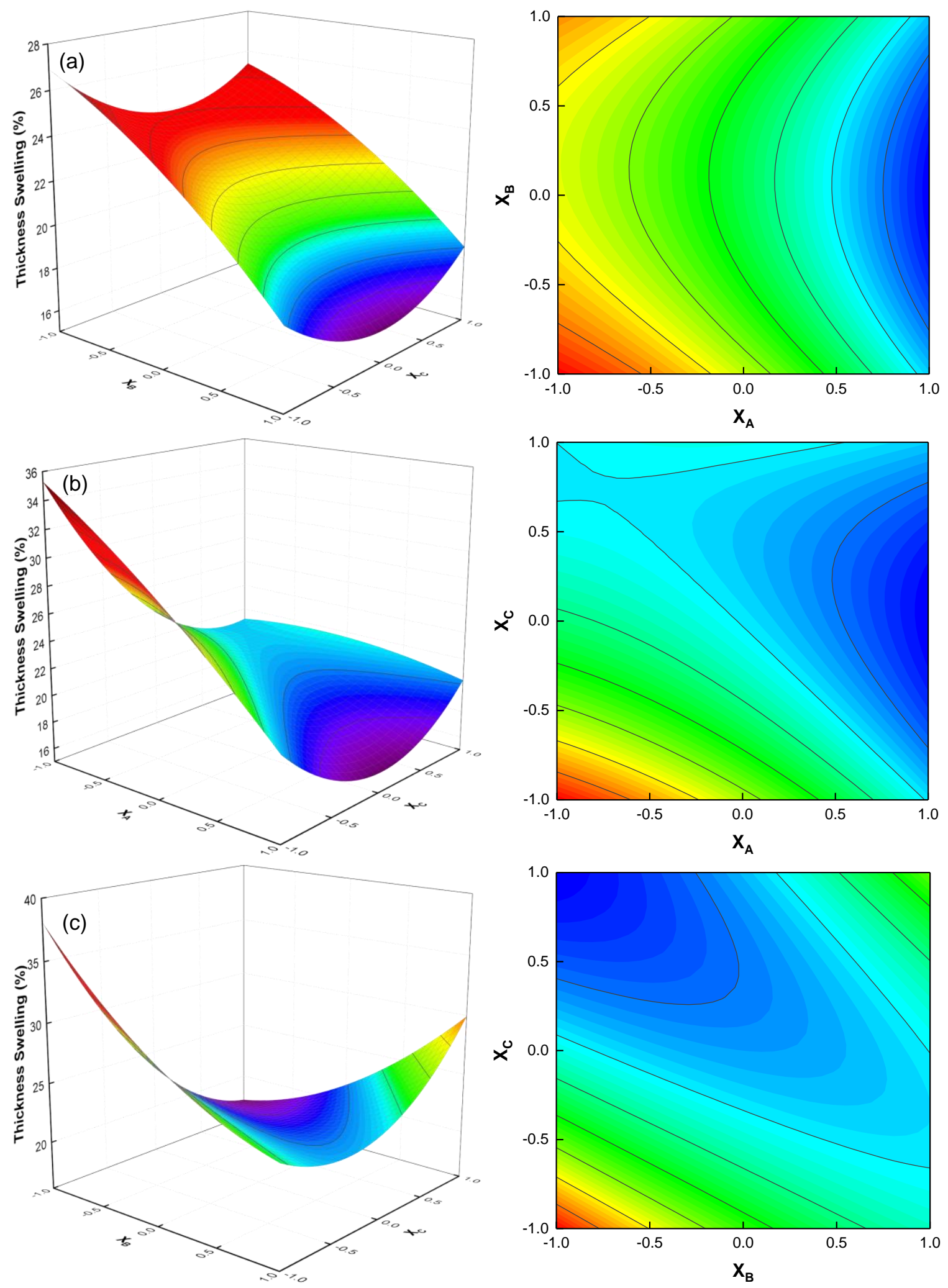

Fig. 4. Response surface plots for TS as a function of: (a) $X_{\mathrm{A}} v s . X_{\mathrm{B}},(\mathrm{b}) X_{\mathrm{A}} v s$. $X_{\mathrm{C}}$, and (c) $X_{\mathrm{B}} v s$. $X_{\mathrm{C}}$ 

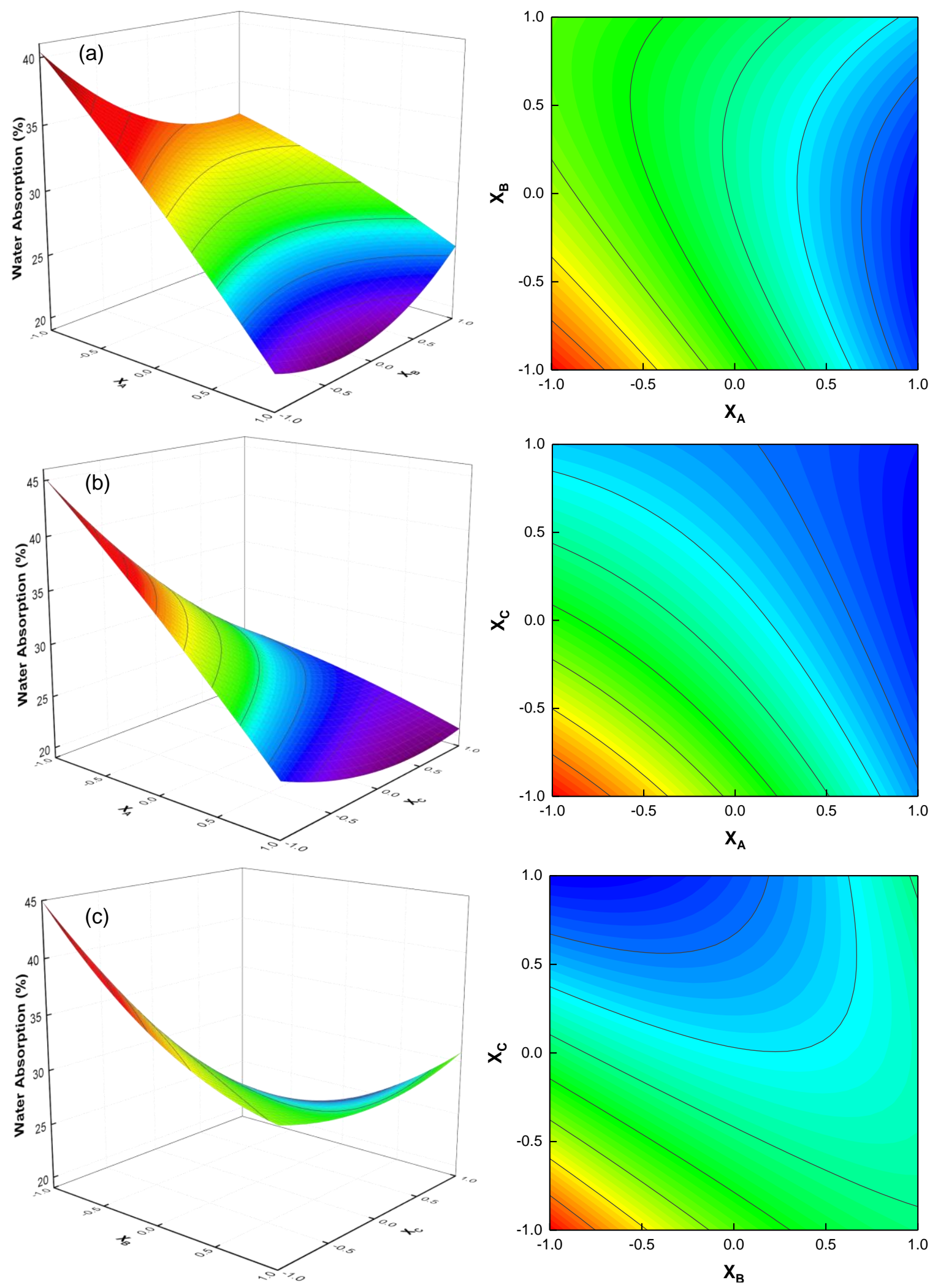

Fig. 5. Response surface plots for WA as a function of: (a) $X_{\mathrm{A}} v s . X_{\mathrm{B}},(\mathrm{b}) X_{\mathrm{A}} v s$. $X_{\mathrm{C}}$, and (c) $X_{\mathrm{B}} v s$. $X_{\mathrm{C}}$ 


\section{Dimensional Stability}

The TS and WA were determined to be the physical properties associated with the dimensional stability of the ECS/HML composites. The TS and WA were measured under different preparation variables. The fitted models for TS and WA yielded $\mathrm{R}^{2}$ values of 0.9808 and 0.9856 , respectively. The added modified lignosulfonate sufficiently improved the TS and WA performances of the ECS/HML composites when compared to the control panels (Table 1). The correlations between the preparation conditions and TS are shown in Figs. 4a to 4c.

Table 2 indicates that both variables $X_{\mathrm{A}}$ and $X_{\mathrm{C}}$ significantly affected the TS while $X_{\mathrm{B}}$ was insignificant. However, interactions between $X_{\mathrm{A}}$ and $X_{\mathrm{B}}$ did not impact the TS while $X_{\mathrm{A}} X_{\mathrm{C}}$ and $X_{\mathrm{B}} X_{\mathrm{C}}$ were significant. Figures $4 \mathrm{a}$ to $4 \mathrm{c}$ overall indicated the response surface plots of different combined experimental parameters. The TS scores of panels reduced as $X_{\mathrm{A}}$ increased at a constant enzymatic pretreatment time $\left(X_{\mathrm{B}}\right)$, suggesting that $X_{\mathrm{A}}$ positively affected the dimensional stability.

Table 2 also shows the correlations between the preparation parameters and the WA behavior of the panels. Interestingly, all variables and interactions between each other were significant for WA. In contrast, although the TS did not significantly improve as the enzymatic pretreatment time increased, the WA noticeably increased at high mass concentrations of laccase-vanillin and elevated modified lignosulfonate dosage at relatively shorter enzymatic pretreatment times (Figs. 5a to 5c). The reason for this has to do with the chemical modification of the particle cell wall and the relief of residual stresses (Ali et al. 2015). Additionally, the addition of HML compacted the board surface by suppressing void spaces, and flowing modified lignin to fill the spaces with covalent interparticle bonds (Back 1987). However, prolonged enzymatic pretreatment time increased the $\mathrm{OH}$ content of corn stalk particle surfaces, facilitating water flow in void spaces, and inducing higher WA values of ECS/HML composites.

\section{Optimization of the Preparation Conditions of the ECS/HML Composites}

The goal was to figure out the optimal preparation conditions that minimized the TS and the WA without significantly compromising the mechanical properties. The predicted experimental conditions with the highest desirabilities were selected for verification. Under these conditions, desirability achieved 0.976 , and the optimum values of manufacturing factors and their responses are given (Table 4).

Table 4. The Optimum Solution Suggested by Design Expert Software

\begin{tabular}{|c|c|c|c|c|c|c|c|c|c|c|c|c|}
\hline \multicolumn{3}{|c|}{$\begin{array}{l}\text { Optimum } \\
\text { Condition }\end{array}$} & \multicolumn{5}{|c|}{ Predicted Data } & \multicolumn{5}{|c|}{ Experimental Data } \\
\hline A & B & C & $\begin{array}{c}\text { MOR } \\
(\mathrm{MPa})\end{array}$ & $\begin{array}{l}\mathrm{MOE} \\
(\mathrm{GPa})\end{array}$ & $\begin{array}{c}\text { IB } \\
(\mathrm{MPa})\end{array}$ & $\begin{array}{c}\text { TS } \\
24 \mathrm{~h} \\
(\%)\end{array}$ & $\begin{array}{l}\text { WA } \\
24 \mathrm{~h} \\
(\%)\end{array}$ & $\begin{array}{l}\text { MOR } \\
(\mathrm{MPa})\end{array}$ & $\begin{array}{l}\text { MOE } \\
(\mathrm{GPa})\end{array}$ & $\begin{array}{c}\text { IB } \\
(\mathrm{MPa})\end{array}$ & $\begin{array}{c}\text { TS } \\
24 \mathrm{~h} \\
(\%)\end{array}$ & $\begin{array}{c}\text { WA } \\
24 \mathrm{~h} \\
(\%)\end{array}$ \\
\hline 1 & 0.99 & 0 & 29.15 & 3.15 & 1.26 & $\begin{array}{c}18.6 \\
3\end{array}$ & 21.71 & $\begin{array}{l}18.4 \\
(3.9)\end{array}$ & $\begin{array}{l}2.79 \\
(4.3)\end{array}$ & $\begin{array}{l}1.15 \\
(5.4)\end{array}$ & $\begin{array}{l}20.1 \\
(2.9)\end{array}$ & $\begin{array}{c}26.1 \\
2 \\
(7.4)\end{array}$ \\
\hline
\end{tabular}

$\mathrm{A}=$ mass concentration of laccase-vanillin $(\mathrm{g} / \mathrm{L}), \mathrm{B}=$ enzymatic pretreated time $(\mathrm{min})$, and $\mathrm{C}=$ modified lignosulfonate dosage (\%)

The predicted responses and experimental test results of the ECS/HML composites were compared with indicated deviations less than 10\%: 3.4\% for MOR, $6.0 \%$ for MOE, $4.6 \%$ for IB, $3.8 \%$ for TS, and $9.2 \%$ for WA. The best values were obtained at high mass 
concentrations of laccase-vanillin, short enzymatic pretreatment times, and appropriate modified lignosulfonate dosages, which fully met GB/T 4897 (2015). The ECS/HML composites showed $47.2 \%$ increase in MOR, $112.9 \%$ increase in MOE and $155.6 \%$ increase in IB compared to the ECS composites without HML binder. Meanwhile the HML binder positively affected he dimensional properties of the ECS/HML Composites, resulting in $25.6 \%$ and $34.7 \%$ decrease in TS and WA. The two-part binder was more effective than the default lignosulfonate binder, which negatively affected TS and WA according to previous reports (Hu and Guo 2015).

\section{Synthesis and Characterization of the ECS/HML Composites}

Hybrid modified lignosulfate was prepared using an oxidation reaction and combination technology through introducing phenolic hydroxyl and amino groups onto an ECS backbone by ether and ester bonds. The FTIR of corn stalk, ECS, ECS/HML composites, HML, and AL are shown in Fig. 6. Comparing the control corn stalk and ECS, the spectra of both corn stalk and ECS had unique patterns with absorption peaks at 1500 $\mathrm{cm}^{-1}$ and $1600 \mathrm{~cm}^{-1}$, due to agricultural lignocellulosic by-products (Buta and Galletti 1989). The -OH bond stretching absorption was discovered between $3309 \mathrm{~cm}^{-1}$ and 3320 $\mathrm{cm}^{-1}$, and the C-H bond stretching absorption of methylene groups was found between 2844 $\mathrm{cm}^{-1}$ to $2925 \mathrm{~cm}^{-1}$. The aromatic ring vibrations of phenylpropane skeleton were noticed at $1600 \mathrm{~cm}^{-1}, 1513 \mathrm{~cm}^{-1}$, and $1430 \mathrm{~cm}^{-1}$.

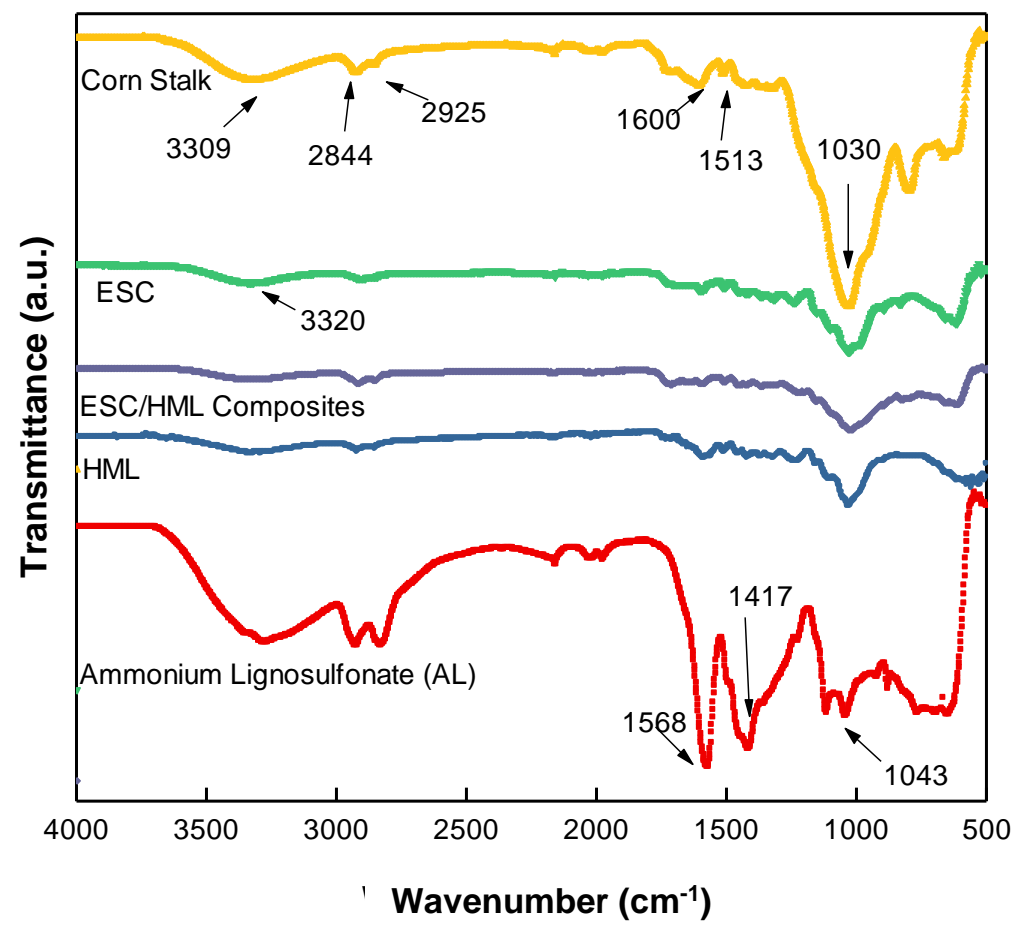

Fig. 6. FTIR spectra of corn stalk, ECS, ECS/HML composites, HML, and AL

The enzymatically treated corn stalks showed lower intensities of syringyl unit (Sbands) from $1328 \mathrm{~cm}^{-1}$ and $1030 \mathrm{~cm}^{-1}$ due to the enzymatic degradation of lignin. The peaks between $1330 \mathrm{~cm}^{-1}$ and $1317 \mathrm{~cm}^{-1}$ were assigned to the cellulose part of the particles with improved crystallinity. The carbonyl band, aldehyde, and carboxyl stretching absorptions 
of the ECS were weakened at $1714 \mathrm{~cm}^{-1}$, indicating that the enzymatic treatment promoted the esterification reaction of lignin on the surface of particles (Nasir et al. 2013). For AL and HML, the methoxyl and sulfonate stretching absorptions of HML were greatly weakened at $1460 \mathrm{~cm}^{-1}$ and $1042 \mathrm{~cm}^{-1}$ to $1044 \mathrm{~cm}^{-1}$, suggesting a possible cleavage reaction in the presence of $\mathrm{H}_{2} \mathrm{O}_{2}$. The FTIR spectrum of HML showed new absorption peaks at $1710 \mathrm{~cm}^{-1}$ and $1225 \mathrm{~cm}^{-1}$ when compared to AL, representing respectively carbonyl stretching and phenolic hydroxyl stretching of HML.
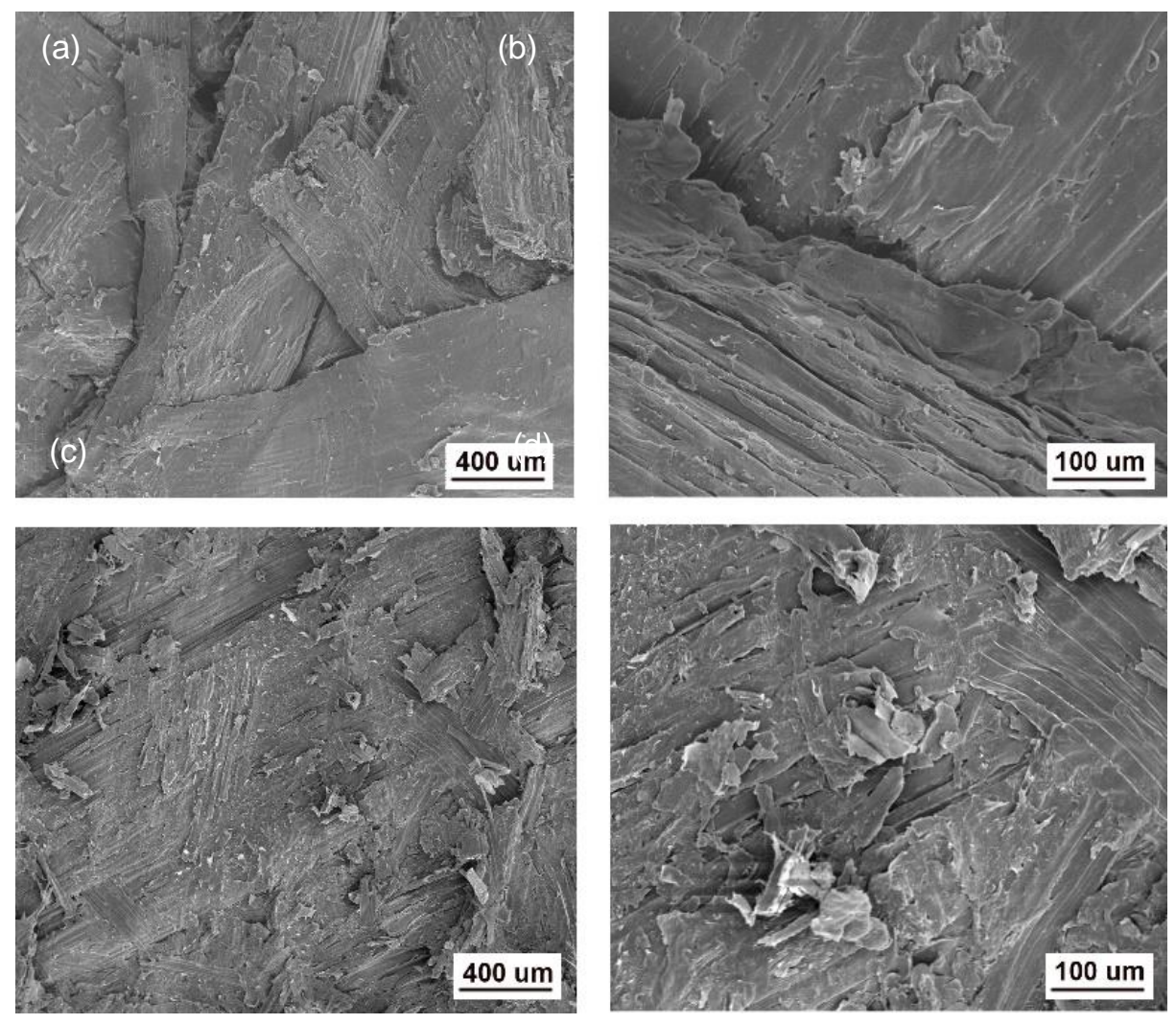

Fig. 7. Micrographs of the ECS panels ( $a$ and $b$ ) and the ECS/HML composites (c and d)

The absorption bands of phenolic hydroxyl, the -OH stretching of the ECS, and the -NH of HML all were weakened after the fabrication of ECS/HML composites. The latter was formed by covalent bonds or ascribed to electrostatic interactions between the ECS and HML (Ji et al. 2017). The differences in the mechanical characteristics of the ECS/HML composites were demonstrated following the IB test shown in Fig. 7. The morphologies of bonding interfaces appeared significantly different. More void spaces were obviously present in the ECS panels when compared to the ECS/HML composites. Moreover, the particle cell walls of the ECS panels almost remained in the original morphologies obtained under hot pressing conditions. Particle debonding clearly occurred in the ECS panels due to poor adhesion, and HML was integrated with the matrix of corn stalk particles in the ECS/HML composites due to good adhesion. Thus, HML looks promising as a binder for corn panels manufacturing. 


\section{CONCLUSIONS}

1. The preparation conditions of enzymatic pretreatment and modification of lignosulfonate dosage improved the dimensional properties of corn stalk biocomposites.

2. The response surface methodology based on the Box-Behnken method was employed to obtain the optimal conditions. The ECS/HML composites treated under optimal conditions resulted in approximately a $42 \%$ reduction of dimensional properties without any significant decline in the mechanical properties when compared to the ECS panels.

3. The statistical analyses demonstrated that individual parameters had more significance than the interactions between these variables. The high mass concentrations of laccasevanillin for relatively short enzymatic pretreatment times and appropriate modified lignosulfonate dosages reduced residual stresses and improved the dimensional properties. The two-part binder was more effective than the default lignosulfonate binder

4. Composites made from enzymatic pretreated corn stalk and modified lignosulfonate can solve ecological problems by using biomass residues for potential applications.

\section{ACKNOWLEDGMENTS}

The authors are grateful for the support of the National Natural Science Foundation of China (Grant No. 31801313); the University Nursing Program for Young Scholars with Creative Talents in Heilongjiang Province (Grant No. UNPYSCT-2018085); the Subproject of National Key Development Plan (Grant No. 2018YFD0800906-03); the Open Foundation of the Heilongjiang Provincial Key Laboratory of Environmental Microbiology and Recycling of Argo-Waste in Cold Region (Grant No. 201708); the Instructional Technology Program in Daqing (Grant No. Zd-2017-79); the Subproject of National Science and Technology Support Plan (Grant No. 2015BAD23B05-07); the Support Plan for "Three Vertical and Three Horizontal" in Heilongjiang Bayi Agricultural University (Grant No. TDJH201809); the Innovation Training Program of the Heilongjiang Provincial College Students (Grant No. 201710223039); and the Innovation Team of Heilongjiang Provincial Key Laboratory (Grant No. 2012TD006).

\section{REFERENCES CITED}

Ali, I., Jayaraman, K., and Bhattacharyya, D. (2015). "Dimensional stability improvement of kenaf panels by post-manufacturing hygrothermal treatments using response surface methodology," Ind. Crop. Prod. 67, 422-431. DOI: 10.1016/j.indcrop.2015.01.071

Alslaibi, T.-M., Abustan, I., Ahmad, M.-A., and Foul, A.-A. (2013). "Cadmium removal from aqueous solution using microwaved olive stone activated carbon," Journal of Environmental Chemical Engineering 1(3), 589-599. DOI:

10.1016/j.jece.2013.06.028 
Angles, M., Reguant, J., Martinez, J., Farriol, X., Montané, D., and Salvadó, J. (1997). "Influence of the ash fraction on the mass balance during the summative analysis of high-ash content lignocellulosics," Bioresource Technol. 59(2), 185-193. DOI: 10.1016/S0960-8524(96)00149-6

Back, E. L. (1987). "The bonding mechanism in hardboard manufacture review report," Holzforschung 41(4), 247-258. DOI: 10.1515/hfsg.1987.41.4.247

Buta, J. G., and Galletti, G. C. (1989). "FT-IR investigation of lignin components in various agricultural lignocellulosic by-prod," J. Sci. Food Agr. 49(1), 37-43. DOI: 10.1002/jsfa.2740490105

Çöpür, Y., Güler, C., Akgül, M., and Taşçığlu, C. (2007). "Some chemical properties of hazelnut husk and its suitability for particleboard production," Build. Environ. 42(7), 2568-2572. DOI: 10.1016/j.buildenv.2006.07.011

GB/T 742 (2008). "Fibrous raw material, pulp, paper and board - Determination of ash," Standardization Administration of China, Beijing, China.

GB/T 744 (2004). "Pulps - Determination of alkali resistance," Standardization Administration of China, Beijing, China.

GB/T 747 (2003). "Fibrous raw material - Determination of acid-insoluble lignin," Standardization Administration of China, Beijing, China.

GB/T 10741 (2008). "Pulps - Determination of alcohol-benzene extractives," Standardization Administration of China, Beijing, China.

GB/T 17657 (2013). "Methods of evaluating the properties of wood-based panels and surface decorated wood-based panels," Standardization Administration of China, Beijing, China.

GB/T 2677.10 (1995). "Fibrous raw material - Determination of holocellulose," Standardization Administration of China, Beijing, China.

GB/T 4897 (2015). "Particleboard," Standardization Administration of China, Beijing, China.

Gao, Y., Yang, A., Bao, J., Ma, R., Yan, L., Wang, Y., and Wang, W. (2017).

"Bioreactor performance and microbial community dynamics in a production-scale biogas plant in northeastern China," Int. J. Agr. Biol. Eng. 10(1), 191-201. DOI: 10.3965/j.ijabe.20171001.2025

González-García, S., Feijoo, G., Heathcote, C., Kandelbauer, A., and Moreira, M. T. (2011). "Environmental assessment of green hardboard production coupled with a laccase activated system," J. Clean. Prod. 19(5), 445-453. DOI:

10.1016/j.jclepro.2010.10.016

Grigoriou, A. H., and Ntalos, G. A. (2001). "The potential use of Ricinus communis L. (Castor) stalks as a lignocellulosic resource for particleboards," Ind. Crop. Prod. 13(3), 209-218. DOI: 10.1016/s0926-6690(00)00078-9

$\mathrm{Hu}$, J. P., and Guo, M. H. (2015). "Influence of ammonium lignosulfonate on the mechanical and dimensional properties of wood fiber biocomposites reinforced with polylactic acid," Ind. Crop. Prod. 78, 48-57. DOI: 10.1016/j.indcrop.2015.09.075

Hu, L., Pan, H., Zhou, Y., and Zhang, M. (2011). "Methods to improve lignin's reactivity as a phenol substitute and as replacement for other phenolic compounds: A brief review," BioResources 6(3), 3515-3525. DOI: 10.15376/biores.6.3.Hu

Ioannidou, O., Zabaniotou, A., Antonakou, E. V., Papazisi, K. M., Lappas, A. A., and Athanassiou, C. (2009). "Investigating the potential for energy, fuel, materials and chemicals production from corn residues (cobs and stalks) by non-catalytic and 
catalytic pyrolysis in two reactor configurations," Renew. Sust. Energ. Rev. 13(4), 750-762. DOI: 10.1016/j.rser.2008.01.004

Jarabo, R., Monte, M. C., Fuente, E., Santos, S. F., and Negro, C. (2013). "Corn stalk from agricultural residue used as reinforcement fiber in fiber-cement production," Ind. Crop. Prod. 43, 832-839. DOI: 10.1016/j.indcrop.2012.08.034

Ji, X., Dong, Y., Yuan, B., Li, B., and Guo, M. (2018). "Influence of glutaraldehyde on the performance of a lignosulfonate/chitosan-based medium density fiberboard adhesive," J. Appl. Polym. Sci. 135(7), 45870-45877. DOI: 10.1002/app.45870

Ji, X., and Guo, M. (2018). "Preparation and properties of a chitosan-lignin wood adhesive," Int. J. Adhes. Adhes. 82, 8-13. DOI: 10.1016/j.ijadhadh.2017.12.005

Ji, X., Li, B., Yuan, B., and Guo, M. (2017). "Preparation and characterizations of a chitosan-based medium-density fiberboard adhesive with high bonding strength and water resistance," Carbohyd. Polym. 176, 273-280. DOI: 10.1016/j.carbpol.2017.08.100

Jin, C. D., Li, S., Liu, L., Ye, J. W., and Du, C. G. (2011). "Research of process on making bamboo particle board by laccase-treated calcium lignosulfonate," Adv. Mat. Res. 179-180, 1031-1036. DOI: 10.4028/www.scientific.net/AMR.179-180.1031

Juárez, C., Durán, A., Valdez, P., and Fajardo, G. (2007). "Performance of 'Agave lecheguilla' natural fiber in portland cement composites exposed to severe environment conditions," Build. Environ. 42(3), 1151-1157. DOI:

10.1016/j.buildenv.2005.12.005

Mancera, C., El Mansouri, N. E., Ferrando, F., and Salvado, J. (2011a). "The suitability of steam exploded Vitis vinifera and alkaline lignin for the manufacture of fiberboard," BioResources 6(4), 4439-4453. DOI: 10.15376/biores.6.4.4439-4453

Mancera, C., El Mansouri, N. E., Vilaseca, F., Ferrando, F., and Salvado, J. (2011b). "The effect of lignin as a natural adhesive on the physico-mechanical properties of Vitis vinifera fiberboards," BioResources 6(3), 2851-2860. DOI: 10.15376/biores.6.3.2851-2860

Muthukumar, M., Mohan, D., and Rajendran, M. (2003). 'Optimization of mix proportions of mineral aggregates using Box Behnken design of experiments," Cement Concrete Comp. 25(7), 751-758. DOI:10.1016/S0958-9465(02)00116-6

Nadhari, W. N. A. W., Hashim, R., Sulaiman, O., Sato, M., Sugimoto, T., and Selamat, M. E. (2013). "Utilization of oil palm trunk waste for manufacturing of binderless particleboard: Optimization study," BioResources 8(2), 1675-1696. DOI: 10.15376/biores.8.2.1675-1696

Nasir, M., Gupta, A., Beg, M. D. H., Chua, G. K., and Kumar, A. (2013). "Fabrication of medium density fibreboard from enzyme treated rubber wood (Hevea brasiliensis) fibre and modified organosolv lignin," Int. J. Adhes. Adhes. 44, 99-104. DOI: 10.1016/j.ijadhadh.2013.02.013

Ndazi, B., Tesha, J. V., Karlsson, S., and Bisanda, E. T. N. (2006). "Production of rice husks composites with Acacia mimosa tannin-based resin," J. Mater. Sci. 41(21), 6978-6983. DOI:_10.1007/s10853-006-0220-7

Shah, D. U. (2013). "Developing plant fibre composites for structural applications by optimising composite parameters: A critical review," J. Mater. Sci. 48(18), 60836107. DOI: $10.1007 / \mathrm{s} 10853-013-7458-7$

Thamae, T., Marien, R., Chong, L., Wu, C., and Baillie, C. (2008). "Developing and characterizing new materials based on waste plastic and agro-fibre," J. Mater. Sci. 43(12), 4057-4068. DOI: 10.1007/s10853-008-2495-3 
Velásquez, J. A., Ferrando, F., and Salvadó, J. (2003). "Effects of kraft lignin addition in the production of binderless fiberboard from steam exploded Miscanthus sinensis," Ind. Crop. Prod. 18(1), 17-23. DOI: 10.1016/s0926-6690(03)00016-5

Wang, D., and Sun, X. S. (2002). "Low density particleboard from wheat straw and corn pith," Ind. Crop. Prod. 15(1), 43-50. DOI: 10.1016/s0926-6690(01)00094-2

Wang, W., Yan, L., Cui, Z., Gao, Y., Wang, Y., and Jing, R. (2011). "Characterization of a microbial consortium capable of degrading lignocellulose," Bioresource Technol. 102(19), 9321-9324. DOI: 10.1016/j.biortech.2011.07.065

Wang, Y., Liu, Q., Yan, L., Gao, Y., Wang, Y., and Wang, W. (2013). “A novel lignin degradation bacterial consortium for efficient pulping," Bioresource Technol. 139, 113-119. DOI: 10.1016/j.biortech.2013.04.033

Widyorini, R., Xu, J., Umemura, K., and Kawai, S. (2005a). "Manufacture and properties of binderless particleboard from bagasse I: Effects of raw material type, storage methods, and manufacturing process," J. Wood Sci. 51(6), 648-654. DOI: 10.1007/s10086-005-0713-z

Widyorini, R., Xu, J., Watanabe, T., and Kawai, S. (2005b). "Chemical changes in steampressed kenaf core binderless particleboard,” J. Wood Sci. 51(1), 26-32. DOI: 10.1007/s10086-003-0608-9

Wu, J., Zhang, X., Wan, J., Ma, F., Tang, Y., and Zhang, X. (2011). "Production of fiberboard using corn stalk pretreated with white-rot fungus Trametes hirsute by hot pressing without adhesive," Bioresource Technol. 102(24), 11258-11261. DOI: 10.1016/j.biortech.2011.09.097

Xu, J., Han, G., Wong, E. D., and Kawai, S. (2003). "Development of binderless particleboard from kenaf core using steam-injection pressing," J. Wood Sci. 49(4), 327-332. DOI: 10.1007/s10086-002-0485-7

Xu, J., Sugawara, R., Widyorini, R., Han, G., and Kawai, S. (2004). "Manufacture and properties of low-density binderless particleboard from kenaf core," J. Wood Sci. 50(1), 62-67. DOI: 10.1007/s10086-003-0522-1

Yan, L., Gao, Y., Wang, Y., Liu, Q., Sun, Z., Fu, B., Wen, X., Cui, Z., and Wang, W. (2012). "Diversity of a mesophilic lignocellulolytic microbial consortium which is useful for enhancement of biogas production," Bioresource Technol. 111, 49-54. DOI: 10.1016/j.biortech.2012.01.173

Yuan, Y., Wang, J., Ni, X., Zhang, X., Yu, F., and Guo, M. (2011). "Processing parameters and performances of eco-friendly fiberboard prepared by laccase modified industial lignins," Journal of Northeast Forestry University 39(5), 81-83.

Yuan, Y., and Guo, M. (2013). "Process research of particleboards using corn stalk pretreated with laccase based on response surface methodology," Journal of Beijing Forestry University 35(4), 112-117.

Yuan, Y., and Guo, M. (2014). "Preparation and characterization of hybrid modified industrial lignin/wood fiber composites," Acta Materiae Compositae Sinica 31(4), 1098-1105.

Yuan, Y., Guo, M., and Liu, F. Y. (2014). "Preparation and evaluation of green composites using modified ammonium lignosulfonate and polyethylenimine as a binder," BioResources 9(1), 836-848. DOI: 10.15376/biores.9.1.836-848

Yuan, Y., and Guo, M. (2016). "Life cycle assessment of hybrid modified industrial lignin /wood fiber composites," Acta Scientiae Circumstantiae 36(11), 4245-4252. DOI: $10.13671 /$ j.hjkxxb.2016.0164 
Yuan, Y., and Guo, M. H. (2017). "Do green wooden composites using lignin-based binder have environmentally benign alternatives? A preliminary LCA case study in China," Int. J. Life. Cycle Assoc. 22(8), 1318-1326. DOI: $10.1007 / \mathrm{s} 11367-016-1235-1$

Zhou, X., Zheng, F., Li, H., and Lu, C. (2010). "An environment-friendly thermal insulation material from cotton stalk fibers," Energ. Buildings 42(7), 1070-1074. DOI: 10.1016/j.enbuild.2010.01.020

Article submitted: December 21, 2018; Peer review completed: March 25, 2019; Revised version received: May 1, 2019; Accepted: May 9, 2019; Published: June 10, 2019. DOI: $10.15376 /$ biores.14.3.5923-5942 